\title{
PENGARUH SUBSTITUSI JUS KULIT BUAH NAGA MERAH (Hylocereus polyrhyzus.) DAN PENAMBAHAN BEKATUL TERHADAP AKTIVITAS ANTIOKSIDAN, KADAR SERAT, DAN MUTU ORGANOLEPTIK MIE BASAH SEHAT
}

\author{
The Effect Of Red Dragon Fruit Substitution (Hylocereus polyrhyzus.) And Addition Of Bulk \\ On Antioxidant Activities, Fiber Levels, And Organoleptic Quality Of Health Wet Mie
}

\author{
Luh Putu Ayu Diah Savitri, I Komang Suwita \\ Jurusan Gizi Poltekkes Kemenkes Malang \\ Email:ksuwita@gmail.com
}

\begin{abstract}
ABSTRAK
Pemanfaatan jus kulit buah naga merah (H.polyrhizus) dan bekatul dalam pembuatan mie basah sehat dapat meningkatkan nilai gizi serta konsumsi pangan yang lebih bervariasi bagi masyarakat luas dan membantu dalam pencegahan penyakit degeneratif. Penelitian ini bertujuan untuk menganalisis pengaruh substitusi jus kulit buah naga merah dan penambahan bekatul terhadap serat kasar, aktivitas antioksidan, mutu organoleptik dan menetukan taraf perlakuan terbaik mie basah. Penelitian ini menggunakan jenis penelitian eksperimen laboratorium dengan desain penelitian Rancangan Acak Lengkap (RAL). Analisis statistik yang digunakan untuk kadar serat dan aktivitas antioksidan adalah One Way Anova, dan untuk mutu organoleptik adalah Kruskall Wallis dengan tingkat kepercayaan 95\%. Perlakuan penelitian adalah substitusi jus kulit buah naga merah dengan proporsi : 3\%, 6\%, 9\%, dan penambahan bekatul sebanyak 5\% dengan replikasi sebanyak 3 kali setiap taraf perlakuan. Hasil penelitian menunjukan bahwa dengan meningkatnya proporsi kulit buah naga merah yang digunakan maka kadar serat kasar dan aktifitas antioksidan semakin meningkat pula. Perlakuan dengan proporsi jus kulit buah naga 9\% dan penambahan bekatul 5\% menunjukkan hasil serat kasar dan aktivitas antioksidan tertinggi yaitu 2,02 gram dan $141,47 \mu \mathrm{g} / \mathrm{ml}$, dan dapat direkomendasikan menjadi taraf perlakuan terbaik.

Kata Kunci: Serat Kasar, Aktivitas Antioksidan, Mie Basah, Kulit Buah Naga, Bekatul
\end{abstract}

\begin{abstract}
Utilization of the red dragon fruit rind juice (H.polyrhizus) and bran in making healthy wet noodles can increase nutritional value and food consumption more diversified to the public and help in the prevention of degenerative diseases. This study aims to analyze the influence of the substitution the red dragon fruit rind juice and the addition of bran to crude fiber, antioxidant activity, the quality of organoleptic and determine the standart treatment for healthy wet noodles. This research uses experimental research with completely randomized design (RAL). Statistical analysis used to level of fiber and antioxidant activity is one way ANOVA, and the quality of organoleptic is Kruskall Wallis with the level of trust $95 \%$. The research treatment is the substitution of the red dragon fruit rind juice with the proportion of each of $3 \%, 6 \%, 9 \%$ respectively, and the addition of bran as many as $5 \%$ with replication about three times every level of treatment. The results of the research showed that the increasing of proportion of red dragon fruit rind which was proposed hence the crude fiber level and antioxidant activity as well increased. The treatment of the proportion of red dragon fruit rind juice of $9 \%$ and the addition off bran $5 \%$ showed that the highest of crude
\end{abstract}


fiber level and antioxidant activity of each of 2.02 gram and $141.47 \mu \mathrm{g} / \mathrm{ml}$ respectively, and can recommended be the best treatment level.

Key words: crude fiber, antioxidant activity, wet noodle, red dragon fruit rind, bran

\section{PENDAHULUAN}

Masalah kesehatan yang masih dihadapi bangsa Indonesia adalah masih tingginya penyakit infeksi dan meningkatnya penyakit degeneratif. Anie (2002) menyebutkan bahwa saat ini penyakit degeneratif dan kardiovaskuler sudah merupakan salah satu masalah kesehatan masyarakat di Indonesia. Menurut World Health Organization (WHO), badan lembaga kesehatan dari PBB, terdapat hampir sekitar 17 juta orang meninggal dunia akibat penyakit degeneratif setiap tahun (Depkes RI, 2005). Salah satu penyebab penyalit degeneratif adalah kurangnya antioksidan yang dapat menetralisir radikal bebas yang terdapat dalam tubuh dan kurangnya serat yang mampu menurunkan tekanan darah dan menurunkan kadar kolesterol. (Astawan dan Wredayati, 2004). Sehingga penyakit degeneratif, perlu dicegah dan diobati dengan merubah pola makan menjadi pola makan sehat yang berpedoman pada aneka ragam makanan yang memenuhi gizi seimbang.

Salah satu makanan paling digemari di Indonesia adalah mie. Saat ini, banyak sekali variasi rasa mie yang terdapat di Indonesia. Kini, mie seperti menjadi makanan pokok saat nasi tidak ada. Pada tahun 2008 total produksi mie Indonesia, baik mi instan, mi kering dan mi basah mencapai 1,6 juta ton, pada tahun 2013 produksinya telah mencapai 2,0 juta ton dan ditahun 2014 mencapai 2,2 juta ton.

Tingginya produksi mie dalam negeri seiiring dengan meningkatnya jumlah penduduk yang menjadikan mie sebagai kebutuhan pokok sehari hari (Amin, 2014). Namun, mengkonsumsi mie terlalu sering sangat tidak baik bagi kesehatan tubuh. Mie mengandung banyak bahan pengawet yang berbahaya bagi tubuh. Berbagai upaya telah dilakukan untuk membuat mie yang sehat dan tidak berbahaya bagi tubuh. Adapun salah satu upaya alternatif untuk membuat mie yang sehat dan aman dikonsumsi adalah dengan memanfaatkan kulit buah naga dan bekatul yang merupakan sumber serat dan antioksidan alami.

Buah naga (Dragon fruit) merupakan buah tropis yang banyak digemari oleh masyarakat karena memiliki khasiat dan manfaat serta nilai gizi cukup tinggi. Prima dan Asri (2012) menyatakan 
bahwa bagian dari buah naga 30-35\% merupakan kulit buah namun seringkali hanya dibuang sebagai sampah. Alangkah baiknya kulit buah naga ini dimanfaatkan, dan salah satu alternatif untuk memanfaatkannya adalah mengolahnya menjadi mie yang sehat dan aman untuk dikonsumsi. Kandungan serat pangan yang terdapat dalam kulit buah naga merah adalah 46,7\% (Saneto, 2005). Dan sebagai bahan yang akan digunakan untuk substitusi dalam pembuatan mie, kulit buah naga merah memiliki kandungan serat yang lebih tinggi bila dibandingkan dengan bahan yang biasanya digunakan sebagai substitusi mie pada umumnya, misalnya bayam hanya memiliki kandungan serat 2,8 gram per100 gram, serat wortel hanya 4 gram per100 gram, dan serat labu kuning hanya 2,4 gram per 100 gram (Astawan dan Wresdiyati, 2004).

Bekatul mungkin masih asing ditelinga masyarakat Indonesia. Jumlah produksi bekatul berbanding lurus dengan produksi beras, artinya di Indonesia yang mayoritas penduduknya menjadikan beras sebagai pangan pokoknya, sehingga hasil samping bekatul pun jumlahnya semakin besar. Bekatul kaya akan vitamin (vitamin B kompleks, terutama B15; dan vitamin E), protein, mineral, lemak, serat, kalsium, asam amino esensial, juga mengandung asam penolik seperti asam ferulat dan diferulat, yang tidak terdapat secara signifikan dalam komoditas buah dan sayur (Adom dan Liu 2002). Selain itu, salah satu komponen paling penting dalam bekatul adalah kandungan antioksidan alami oryzanol. Oryzanol adalah antioksidan yang hanya terdapat pada bekatul, sangat kuat dalam mencegah oksidasi, dan lebih efektif mencegah radikal bebas dibanding vitamin $\mathrm{E}$ (Hadipernata, 2007). Keuntungan fisiologis dari bekatul padi sebagai sumber bahan pangan adalah karena kandungan vitamin $\mathrm{E}$ dan oryzanol yang juga berperan dalam penurunan kolesterol (Damayanthi, 2007).

Minat masyarakat di Indonesia terhadap produk mie cukup tinggi. Oleh karena itu, pengembangan produk mie dengan substitusi jus kulit buah naga merah dan penambahan bekatul sebagai pangan fungsional diharapkan dapat menjadi mie sehat yang mampu mencegah penyakit degeneratif bila dikonsumsi sebagai makanan alternatif.

\section{METODE PENELITIAN}

Penelitian dilaksanakan pada bulan Februari - April 2016 di Laboratorium Ilmu Bahan Makanan (IBM) Jurusan Gizi 
Politeknik Kesehatan Kemenkes Malang untuk penelitian utama, meliputi pengolahan mie dengan substitusi jus buah naga merah dan bekatul, serta pengujian organoleptik mei. Laboratorium Teknologi Pangan Jurusan Teknologi Hasil Pertanian Universitas Brawijaya Malang untuk uji kadar serat dan aktivitas antioksidan.

Bahan yang digunakan dalam pembuatan mei adalah tepung terigu protein tinggi dan sedang, tepung tapioka, bahan pengenyal (STPP/CMC), telur, kulit buah naga merah, bekatul, minyak goreng.

Bahan untuk analisis : reagen DPPH, etanol $80 \%$, larutan $\mathrm{H}_{2} \mathrm{SO}_{4}$, kertas saring, $\mathrm{NaOH} 1,25 \%$, kalium sulfat $10 \%$, aquades, alkohol $95 \%$.

Alat yang digunakan dalam pembuatan mei adalah timbangan triple beam, baskom, sendok, panci, kompor, penggiling mie. Dan alat yang digunakan untuk analisis adalah: timbangan digital analitik, spektofotometri, oven, desikator, kertas saring, erlenmeyer, pipet tetes, spatula, exstaktor soxlet, tabung reaksi.

Jenis penelitian ini adalah penelitian eksperimen laboratorium dengan desain penelitian Rancangan Acak Lengkap (RAL). Perlakuan penelitian adalah substitusi jus kulit buah naga merah dan penambahan bekatul pada produk mie basah yang terdiri dari 3 taraf perlakuan yaitu substitusi jus kulit buah naga sebagai bahan substitusi dengan proporsi $0 \%, 3 \%, 6 \%$, dan $9 \%$. Sedangkan penambahan bekatul sebanyak 5\% pada setiap taraf perlakuan. Masing-masing taraf perlakuan diulang sebanyak 3 kali, sehingga terdapat 12 unit eksperimen. Analisis dilakukan meliputi kadar serat, aktivitas antioksidan, mutu organoleptik, dan penentuan taraf perlakuan terbaik.

\section{Penelitian Pendahuluan}

Penelitian pendahuluan dilakukan dengan penentuan proporsi substitusi jus kulit buah naga merah dan penambahan bekatul pada produk mie basah. Penentuan proporsi didasarkan pada kebutuhan zat gizi (2250 kalori), kemampuan bahan dalam membentuk mie dengan karakteristik fisik dan komposisi zat gizi yang baik.

\section{Penelitian Utama}

Penelitian utama dilakukan dalam 3 tahap, yaitu: 1) Pengolahan Mie Basah diawali dengan persiapan bahan yang meliputi pembuatan jus kulit buah naga, 2) Formulasi bahan utama yaitu tepung terigu, tepung tapioka, bahan pengenyal 
(STPP/CMC), dan telur, bekatul dan jus kulit buah naga, 3) Pengolahan mie.

Analisis Kadar Serat (Sulaeman, A dkk, 1995).

Analisis serat total dilakukan dengan metode acid alkali digestion menggunakan alat Fibertec System M.

Uji Aktivitas Antioksidan (Herawati, 2012)

Uji yang digunakan untuk menentukan aktivitas antioksidan penangkap radikal bebas adalah dengan metode DPPH. Metode ini memberikan informasi reaktivitas senyawa yang diuji dengan radikal bebas stabil DPPH memberikan serapan kuat pada panjang gelombang 517 $\mathrm{nm}$ dengan warna violet gelap. Penangkapan radikal bebas menyebabkan elektron menjadi berpasangan yang kemudian menyebabkan penghilangan warna yang sebanding dengan jumlah elektron yang diambil (Sunarmi 2005 dalam Sunardi 2007). Standar uji aktivitas antioksidan menurut Phongpaichit et al., 2007 dalam Handayani, 2014 adalah sebagai berikut : sangat kuat IC50< 10 $\mu \mathrm{g} / \mathrm{ml}$, kuat IC50 $10-50 \mu \mathrm{g} / \mathrm{ml}$, sedang IC50 50-100 $\mu \mathrm{g} / \mathrm{ml}$, lemah IC50 100-250 $\mu \mathrm{g} / \mathrm{ml}$, tidak aktif IC50 > $250 \mu \mathrm{g} / \mathrm{ml}$.

\section{Uji Mutu organoleptik}

Uji mutu organoleptik digunakan dengan metode hedonic scale test menurut Soekarto, (1985) yang bertujuan untuk mengetahui daya terima terhadap mie basah dengan substitusi jus kulit buah naga merah dan penambahan bekatul.

\section{Penentuan taraf perlakuan terbaik}

Penentuan taraf perlakuan terbaik menggunakan metode indeks efektivitas. Metode tersebut dilakukan dengan cara mengukur beberapa variabel yang mempengaruhi mutu hasil substitusi jus kulit buah naga merah dan penambahan bekatul pada mie basah seperti kadar serat, aktivitas antioksidan dan mutu organoleptik.

\section{HASIL DAN PEMBAHASAN}

\section{Kadar Serat}

Konsumsi serat pangan yang cukup sangat penting untuk mencegah timbulnya penyakit diabetes melitus, penyakit jantung koroner, dan membantu metabolisme lemak, memelihara kesehatan mukosa usus dan fungsi kolon secara normal. Hasil analisis kadar serat pada produk mie basah subtitusi jus kulit buah naga merah dan penambahan bekatul dapat dilihat pada Tabel 1 . 
Tabel 1. Kadar Serat kasar Mie Basah per 100 gram

\begin{tabular}{|l|c|}
\hline $\begin{array}{l}\text { Taraf perlakuan } \\
\text { Tepung Terigu }: \text { Jus Kulit } \\
\text { Buah Naga Merah + Bekatul }\end{array}$ & Kadar Serat Kasar $(\mathrm{g})$ \\
\hline P0 $(100: 0: 0)$ & $0,95^{\mathrm{a}}$ \\
\hline P1 $(92: 3: 5)$ & $1,26^{\mathrm{b}}$ \\
\hline P2 $(89: 6: 5)$ & $1,89^{\mathrm{c}}$ \\
\hline P3 $(86: 9: 5)$ & $2,02^{\mathrm{d}}$ \\
\hline
\end{tabular}

Keterangan: Notasi yang berbeda menunjukkan adanya perbedaan yang signifikan $(\alpha=$ $0,05)$

Tabel 1 menunjukkan bahwa kadar serat kasar mie basah berkisar antara 0,95 $-2,02$ g. Kadar serat kasar mei basah yang terendah adalah pada taraf mei basah kontrol (P0) yaitu 0,95 g, sedangkan kadar serat kasar tertinggi adalah pada taraf perlakuan P3 (2,02 g). Hasil analisis statistik One Way Anova pada tingkat kepercayaan 95\% menunjukkan bahwa terdapat pengaruh yang signifikan $(\mathrm{p}=0,000)$ substitusi jus kulit buah naga dan penambahan bekatul terhadap kadar serat yang dihasilkan mei basah. Hasil uji lanjut DMRT menunjukkan bahwa kadar serat kasar mei basah kontrol (P0) berbeda nyata secara statistik dengan mei basah perlakuan P1, P2 dan P3. Dan P1 berbeda nyata dengan $\mathrm{P} 2$ dan $\mathrm{P} 3$, serta $\mathrm{P} 2$ berbeda nyata dengan P3. Hal ini disebabkan karena kulit buah naga merah mengandung serat yang cukup tinggi, kulit buah naga merah memiliki serat sebanyak $46,7 \%$ (Saneto, 2005), sehingga dengan semakin meningkatnya proporsi kulit buah naga merah yang digunakan maka semakin meningkat pula serat kasar pada mei basah.

Satu gram serat kasar setara dengan 2 sampai 3 gram serat pangan (Tejasari, 2005). Hasil uji kadar serat kasar menunjukkan 0,95 gram hingga 2,02 gram, hal ini berarti serat pangan yang terkadung dalam mie basah adalah 2,38 gram untuk mie kontrol (P0); 3,15 gram untuk $\mathrm{P} 1 ; 4,73$ gram untuk $\mathrm{P} 2$; dan 5,05 gram untuk P3.

Dalam pembagian makanan sehari, makanan dibagi menjadi 3 kali makan utama dan 2 kali makan snack. Mie termasuk produk makanan utama dengan takaran saji 200 gram setiap kali makan (Sutomo, 2008). Dan serat dibutuhkan tubuh 25 gram hingga 30 gram perhari (Astawan dan Wresdiyati, 2004). Sehingga rata-rata setiap kali makan membutuhkan serat sebanyak 8 gram. Bila dibandingkan dengan kebutuhan tersebut, produk mie basah substitusi kulit buah 
naga merah dan penambahan bekatul (ROS), mampu menghambat terjadinya sudah mencukupi kebutuhan serat setiap penyakit degeneratif serta mampu kali makan, karena serat yang terkandung menghambat peroksidasi lipid pada dalam mie basah mencapai 10,1 gram makanan. Antioksidan alami banyak dalam 200 gram mie untuk setiap kali terdapat pada bahan makanan, salah mengkonsumsi mie basah.

\section{Aktivitas Antioksidan}

Antioksidan alami mampu penambahan bekatul dapat dilihat pada melindungi tubuh terhadap kerusakan Tabel 2. yang disebabkan spesies oksigen reaktif

Tabel 2. Aktivitas Antioksidan Mie Basah

\begin{tabular}{|l|c|c|}
\hline \multicolumn{1}{|c|}{ Taraf perlakuan } & $\begin{array}{c}\text { Aktivitas antioksidan } \\
(\boldsymbol{\mu g} / \mathbf{m l})\end{array}$ & Keterangan \\
\hline $\mathrm{P} 0(100: 0: 0)$ & $306,07^{\mathrm{a}}$ & Tidak Aktif \\
\hline $\mathrm{P} 1(92: 3: 5)$ & $172,84^{\mathrm{b}}$ & Lemah \\
\hline $\mathrm{P} 2(89: 6: 5)$ & $163,56^{\mathrm{c}}$ & Lemah \\
\hline $\mathrm{P} 3(86: 9: 5)$ & $141,47^{\mathrm{d}}$ & Lemah \\
\hline
\end{tabular}

Keterangan: Notasi yang berbeda menunjukkan adanya perbedaan yang signifikan $(\alpha=$ $0,05)$

Berdasarkan Tabel 2 terlihat bahwa

kulit buah naga dan penambahan bekatul rata-rata hasil uji aktivitas antioksidan memberi pengaruh signifikan terhadap menggunakan uji IC50 berkisar antara kandungan aktivitas antioksidan $(\mathrm{p}=0,00)$ 141,47-172,84 $\mu \mathrm{g} / \mathrm{ml}$. Hal ini mengambarkan bahwa antioksidan yang terdapat pada produk mie basah hasil subtitusi jus kulit buah naga merah dan penambahan bekatul masih tergolong aktif meskipun dalam kategori lemah. Aktifitas antioksidan tertinggi terdapat pada perlakuan P3 yaitu 141,47 $\mu \mathrm{g} / \mathrm{ml}$. Hasil analisis statistik Oneway Anova pada tingkat kepercayaan 95\% menunjukkan bahwa proporsi substitusi pada mie basah. Hasil uji lanjut menggunakan Duncan Multiple Range Test (DMRT) menunjukkan bahwa aktivitas antioksidan mei kontrol (P0) dan setiap perlakuan (P1, P2 dan $\mathrm{P} 3)$ terdapat perbedaan yang nyata secara statistik. Hal ini dipengaruhi oleh semakin bertambahnya proporsi kulit buah naga merah yang digunakan pada setiap taraf perlakuan. Menurut Nurliyana, R,. et al., 2010, dalam $1 \mathrm{mg} / \mathrm{ml}$ kulit buah naga 
merah mampu menghambat sebanyak $83,48 \pm 1,02 \%$ radikal bebas

Menurut Jaafar et al. (2009), kulit buah naga memiliki potensi sebagai antioksidan yang lebih tinggi daripada dagingnya. Dengan meningkatnya proporsi jus kulit buah naga yang digunakan menyebabkan peningkatan aktivitas antioksidan, namun dalam penelitian ini tidak memperhatikan umur buah naga setelah panen sehingga kemungkinan ada faktor yang berpengaruh terhadap aktivitas antioksidan.

Bekatul memiliki kandungan oryzanol yang cukup tinggi, yaitu 1,68 mg/g (Kusbiantoro dan Rakhmi, 2009). Selain itu aktivitas antioksidan kulit buah naga (IC50 $=0,3 \mu \mathrm{g} / \mathrm{mL})$ juga lebih tinggi daripada aktivitas antioksidan daging buahnya (IC50 $>1 \mu \mathrm{g} / \mathrm{mL}$ ) (Ekawati, dkk, 2015).

Aktivitas antioksidan pada produk mie basah yang tergolong dalam kategori lemah, kemungkinan juga disebabkan

karena pengaruh proses pengolahan pada pembuatan mei dengan menggunakan pemanasan. Proeses dengan panas tersebut dapat merusak antioksidan pada mei basah yang menyebabkan aktivitas antioksidan menjadi lemah. Suhu maksimal oryzanol adalah $100-120^{\circ} \mathrm{C}$, dan dengan penambahan jus kulit buah naga merah dengan tujuan meningkatkan kandungan antioksidan (antosianin), akan tetapi antosianin akan rusak jika dipanaskan pada suhu lebih dari $100^{\circ} \mathrm{C}$ dalam waktu yang cukup lama (Ibrahim, dkk, 2015).

\section{MUTU ORGANOLEPTIK}

Pengukuran sifat fisik pangan seperti warna, aroma, rasa dan tekstur sangat diperlukan karena sifat tersebut mempengaruhi penampilan dan daya terima produk pangan. Uji mutu organoleptik dilakukan oleh panelis agak terlatih yang berjumlah 20 orang. Pengamatan meliputi rasa, warna, aroma dan tekstur mei basah. Tabel 3. Tingkat Kesukaan Panelis terhadap Warna, Aroma, Rasa, dan Tekstur Mie Basah subtitusi jus kulit buah naga merah dan penambahan bekatul

\begin{tabular}{|l|l|l|l|l|}
\hline $\begin{array}{l}\text { Taraf Perlakuan }(\%) \\
\text { (Tepung Terigu : Jus Kulit }\end{array}$ & Warna & Aroma & Rasa & Tekstur \\
\hline $\mathrm{P} 0(100: 0: 0)$ & $3,5 \pm 0,8^{\mathrm{a}}$ & $2,7 \pm 0,9^{\mathrm{a}}$ & $2,8 \pm 0,7^{\mathrm{a}}$ & $3,1 \pm 0,8^{\mathrm{a}}$ \\
\hline $\mathrm{P}_{1}(92: 3: 5)$ & $2,7 \pm 0,6^{\mathrm{b}}$ & $2,9 \pm 0,6^{\mathrm{a}}$ & $2,7 \pm 0,7^{\mathrm{a}}$ & $3,2 \pm 0,7^{\mathrm{a}}$ \\
\hline $\mathrm{P}_{2}(89: 6: 5)$ & $2,7 \pm 0,7^{\mathrm{bc}}$ & $2,8 \pm 0,9^{\mathrm{a}}$ & $2,7 \pm 0,7^{\mathrm{a}}$ & $3,0 \pm 0,6^{\mathrm{a}}$ \\
\hline $\mathrm{P}_{3}(86: 9: 5)$ & $2,8 \pm 0,9^{\mathrm{ac}}$ & $2,8 \pm 0,8^{\mathrm{a}}$ & $2,7 \pm 0,7^{\mathrm{a}}$ & $3,0 \pm 0,8^{\mathrm{a}}$ \\
\hline
\end{tabular}

Notasi yang berbeda menunjukkan adanya perbedaan yang signifikan $(\alpha=0,05)$ 
Keterangan: 4=sangat suka; $3=$ suka, $2=$ tidak suka; $1=$ sangat tidak suka

Warna

Berdasarkan Tabel 3 di atas, Tingkat penerimaan panelis terhadap warna menunjukan kisaran 2,7-3,5 yang didasarkan pada skala 1-4 (sangat tidak suka-sangat suka). Pada mei basah kontrol dengan tingkat penerimaan tertinggi yaitu rata-rata 3,5 (suka), dan terjadi penurunan tingkat penerimaan terhadap warna pada mei basah subtitusi jus kulit buah naga merah dan penambahan bekatul (P1, P2) yaitu dengan tingkat penerimaan rata-rata 2,7 , dan P3 (2,8). Panelis cenderung lebih menyukai warna dari mei basah kontrol (P0). Hal ini dikarenakan P0 merupakan warna asli mie basah. Sedangkan mei basah yang disubstitusi jus kulit buah naga dan penambahan bekatul menyebabkan perubahan warna menjadi lebih merah muda. Namun dari tiga taraf perlakuan yang telah dilakukan, taraf perlakuan P3 dengan substitusi jus kulit buah naga $9 \%$ dan penambahan bekatul sebesar 5\% merupakan perlakuan dengan tingkat kesukaan terbaik dari segi warna, yang ditunjukkan dengan rata-rata tingkat kesukaan 2,8. Hasil analisis statistik Kruskal Wallis pada tingkat kepercayaan 95\% menunjukan bahwa proporsi substitusi jus kulit buah naga merah dan penambahan bekatul memberikan pengaruh yang signifikan $(\mathrm{p}=0,003)$ terhadap warna mie basah. Uji lanjut Mann-Whitney menunjukkan bahwa warna mei basah pada taraf perlakuan P0 dengan P1 dan P2, dan taraf perlakuan P1 dengan P3 terdapat perbedaan yang signifikan.

Kulit buah naga mengandung pigmen antosianin yang bersifat antioksidan. Antosianin merupakan zat warna yang berperan memberikan warna ungu, berpotensi menjadi pewarna alami untuk pangan dan dapat dijadikan alternatif pengganti pewarna sintetis yang lebih aman bagi kesehatan (Citramukti, 2008). Meningkatnya penambahan kulit buah naga merah menyebabkan peningkatan warna merah pada mie basah yang dihasilkan.

\section{Aroma}

Tingkat kesukaan panelis terhadap aroma mie basah (Tabel 3) berkisar antara 2,7-2,9, dengan tingkat penerimaan kesukaan terendah terhadap aroma adalah P0. Perlakuan substitusi jus kulit buah naga merah dan penambahan bekatul pada mie basah yang paling disukai adalah taraf perlakuan P1. Hal ini dikarenakan aroma langunya masih sangat kurang yang berasal dari 
penggunaan juskulit buah naga yang sedikit dibandingkan taraf perlakuan P2 dan P3 yang menggunakan jus kulit buah naga yang proporsinya semakin meningkat. Menurut Eka Pratiwi, dkk dalam Kemala, (2015), buah naga merah cenderung memiliki aroma yang kuat sehingga diperlukan pengolahan lebih lanjut. Aroma yang dihasilkan mie basah adalah langu berasal dari tepung bekatul. Banyaknya konsentrasi tepung bekatul yang digunakan membuat aroma langu tersebut semakin terasa (Fitriyaningsih, 2011). Namun demikian, hasil uji analisis statistik Kruskal Wallis pada tingkat kepercayaan 95\% menunjukkan bahwa tidak ada pengaruh yang signifikan $(\mathrm{p}=$ $0,824)$ terhadap aroma mie basah. Hal ini menunjukkan bahwa aroma mie basah dengan substitusi jus kulit buah naga merah dan penambahan bekatul pada tiap taraf perlakuan relatif sama.

\section{Rasa}

Hasil uji tingkat kesukaan terhadap rasa mei basah (Tabel 3) didapat rata-rata tingkat kesukaan 2,7-2,8), dengan tingkat kesukaan terhadap rasa tertinggi pada P0 $(2,8)$. Tingkat kesukaan terhadap warna terjadi penurunan pada $\mathrm{P} 1, \mathrm{P} 2$, dan $\mathrm{P} 3$ (rata-rata 2,7) seiring dengan perlakuan subtitusi jus kulit buah naga merah dan penambahan bekatul. Hasil analisis

statistik Kruskal Wallis pada tingkat kepercayaan 95\% menunjukkan bahwa tidak ada pengaruh yang signifikan $(p=0,939)$ terhadap rasa mie basah. Hal ini berarti rasa mie basah dengan substitusi jus kulit buah naga merah dan penambahan bekatul pada tiap taraf perlakuan relatif sama.

Penambahan bekatul dapat mengurangi tingkat penerimaan panelis, dikarenakan banyaknya konsentrasi bekatul yang digunakan membuat rasa after taste berupa rasa agak pahit pada mie basah. (Fitriyaningsih, dkk. 2015). Menurunya tingkat kesukaan panelis terhadap mie basah dikarenakan kulit buah naga memberikan rasa pekat sehingga tidak disukai panelis. (Ekawati, P., dkk. 2015).

\section{Tekstur}

Tingkat penerimaan panelis terhadap tekstur (Tabel 3) rata-rata tertinggi adalah 3,2 (P1). Tingkat penerimaan mie basah semakin menurun seiring dengan meningkatnya proporsi penggunaan jus kulit buah naga merah. Hasil analisis statistik Kruskal Wallis pada tingkat kepercayaan 95\% menunjukkan bahwa tidak ada pengaruh yang signifikan $(p=0,837)$ terhadap tekstur mie basah, artinya bahwa substitusi jus kulit buah 
naga merah dan penambahan bekatul pada tiap taraf perlakuan relatif sama.

Menurut Estiasih (2006) dalam Wahyuni dan Nugroho (2014) karena kemampuannya berikatan hidrogen dengan air, polisakarida mampu menyerap air dan menahannya dalam struktur molekulnya. Pada keadaan setimbang, polisakarida dapat menahan air 8-12\%. Pada kondisi lingkungan yang kadar airnya tinggi polisakarida dapat menyerap air, membengkak dan kemudian mengalami pelarutan sehingga menghasilkan produk mie yang mempunyai tekstur yang tidak mudah putus karena terbentuk gel.

\section{Penentuan Taraf Perlakuan Terbaik}

Penentuan pemilihan perlakuan terbaik menggunakan parameter aktivitas antioksidan, kadar serat, dan mutu organoleptik (warna, aroma, rasa, tekstur). Variabel aktivitas antioksidan merupakan variabel terpenting dalam penentuan taraf perlakuan terbaik. Berdasarkan kriteria tersebut diperoleh mie basah substitusi jus kulit buah naga merah dengan proporsi 9\% (P3) sebagai taraf perlakuan terbaik mie basah dengan aktivitas antioksidan 141,47 $\mu \mathrm{g} / \mathrm{ml}$ kadar serat pangan 2,02 gram.

\section{KESIMPULAN}

Substitusi jus kulit buah naga merah dan penambahan bekatul memberikan berpengaruh yang signifikan terhadap pertambahan kadar serat dan aktivitas antioksidan. Semakin meningkat proporsi jus kulit buah naga merah, maka semakin meningkat pula kadar serat dan aktivitas antioksidan mei basah.

Substitusi jus kulit buah naga merah dan penambahan bekatul memberikan pengaruh yang signifikan terhadap warna, namun tidak memberikan pengaruh yang nyata terhadap aroma, rasa dan tekstur mei basah.

Untuk perlakuan terbaik mie basah substitusi jus kulit buah naga merah dan penambahan bekatul adalah P3 dengan aktivitas antioksidan 141,47 $\mu \mathrm{g} / \mathrm{ml}$ dan kadar serat pangan 2,02 gram.

\section{Saran}

Agar antioksidan pada produk olahan yang berbahan jus kulit buah naga merah dapat dipertahankan, maka sangat penting memperhatikan suhu dalam proses pengolahan dalam pembuatan mei basah, ataupun dapat diolah menjadi bentuk produk yang lain dengan menggunakan suhu yang tidak terlalu tinggi agar kandungan antioksidan pada produk yang 
dihasilkan tidak banyak yang hilang atau

rusak akibat tingginya suhu pengolahan.

\section{DAFTAR PUSTAKA}

Astawan, M. dan Wresdiyati, T. (2004). Diet Sehat dengan Makanan Berserat. Solo: Tiga Serangkai

Damayanti, E., Tjing L. T., dan Arbianto L. (2007). Rice Bran. Depok: Penebar Swadaya.

Ekawati, P., dkk. (2015). Aplikasi Ekstrak Kulit Buah Naga Sebagai Pewarna Alami pada Susu Kedelai dan Santan. J. Agrotekbis, Vol 3 (2),198-205

Hadipernata, Mulyana. (2007). Mengolah Dedak Menjadi Minyak (Rice Bran Oil). Warta Penelitian dan Pengembangan Pertanian Vol 29 (4)

Kumalaningsih, S. (2006). Antioksidan Alami. Surabaya: Trubus Agrisarana.

Kusbiantoro, B. dan Rakhmi A. (2011). Review : Gamma Oryzanol
Potensi Tersembunyi Dalam Produk Samping Padi (Online) http:// litbang.pertanian.go.id, diakses tanggal 22 Desember 2015)

Saneto, B. (2005). Karakteristik Kulit Buah Naga Merah (H. polyrhizus). (Online) (http://widyagama.ac.id/pertanian/w p- content/uploads/2012/01/5budis.pdf, diakses tanggal 7 Juni 2015)

Sutomo, B. (2008). Variasi Mi \& Pasta. Jakarta: Kawan Pustaka

Tejasari. (2005). Nilai Nilai Gizi Pangan. Yogyakarta: Graha Ilmu

Wahyuni, R. (2011). Pemanfaatan Kulit Buah Naga Supermerah (Hylicereus costaricensis) sebagai Sumber Antioksidan dan Pewarna Alami Pada Pembuatan Jelly. $J$. Teknologi Pangan, Vol. 2 (1).

Wahyuni, R dan Nugroho M. (2014). Pengaruh Penambahan Ekstrak Kulit Buah Naga Super Merah terhadap Produk Mie Kering. J. Teknologi Pertanian, Vol. 15 (2) : 93 - 102 